\title{
PENGARUH PIJAT OKETANI TERHADAP KELANCARAN ASI DAN TINGKAT KECEMASAN PADA IBU NIFAS
}

\author{
${ }^{1}$ Siti Novy Romlah, ${ }^{2}$ Junaida Rahmi \\ 1,2 Program Studi D3 Kebidanan STIKes Widya Dharma Husada Tangerang, \\ ${ }^{1}$ sitinovyromlah@wdh.ac.id, ${ }^{2}$ junaidarahmi@wdh.ac.id
}

\begin{abstract}
ABSTRAK
Latar Belakang Cakupan ASI eksklusif di Indonesia pada tahun 2010 adalah 33,6\%, meningkat menjadi 38,5\% pada tahun 2011 dan $42 \%$ pada tahun 2012 serta mengalami penurunan pada tahun 2013 menjadi 30,2\%. Hasil cakupan ASI eksklusif belum mencapai target yang diinginkan secara Nasional yaitu sebanyak $80 \%$. Tujuan Penelitian ini diketahui pengaruh pijat oketani terhadap kelancaran ASI dan tingkat kecemasan pada ibu nifas. Desain penelitian yang digunakan adalah quasi experiment dengan rancangan "One Groups Pretest-Posttest Design" yaitu desain penelitian yang terdapat pretest sebelum diberi perlakuan dan posttest setelah perlakuan. Hasil Penelitian mean kelancaran ASI sebelum dan sesudah pijat oketani pada ibu nifas adalah 10,3 dan 12,5, hasil uji t dependen menunjukkan ada perbedaan kelancaran sebelum dan sesudah dilakukan pijat oketani pada ibu nifas $(\mathrm{p}=0,016)$. mean tingkat kecemasan sebelum dan sesudah dilakukan pijat oketani pada ibu nifas adalah 35,11 dan 13,33. Hasil uji t dependen menunjukkan ada perbedaan tingkat kecemasan sebelum dan sesudah dilakukan pijat oketani pada ibu nifas ( $\mathrm{p}=0,006)$.
\end{abstract}

Kata Kunci : Pijat Oketani, Tingkat Kecemasan, Kelancaran ASI.

\section{THE EFFECT OF OKETANI MASSAGE TO THE EJECTION OF BREAST MILK AND LEVEL OF ANXIETY IN POST PARTUM MOTHER}

\begin{abstract}
Background Coverage of exclusive milk in Indonesia in 2010 was 33.6\%, increased to $38.5 \%$ in 2011 and $42 \%$ in 2012 and decreased in 2013 to 30, 2\%. The results of exclusive breastfeeding coverage have not reached the desired national target of $80 \%$. The purpose study is the effect Oketani massage to the ejection of breast milk and anxiety levels in postpartum mothers. The research design used a quasi experiment with the design of one groups pretestposttest design that contained pretest before being given treatment and posttest after treatment. Research result the mean the ejaction of breast milk before and after Oketani massage in postpartum mothers is 10.3 and 12.5, the results of the dependent $t$ test showed that there were differences in the ejaction of breast milk before and after doing Oketani massage in postpartum mothers $(p=0.016)$. The mean level of anxiety before and after doing Oketani massage in postpartum mothers was 35.11 and 13.33. Dependent t test results showed that there were differences in the level of anxiety before and after doing the Oketani massage in postpartum mothers $(p=0.006)$.
\end{abstract}

Keywords: Oketani Massage, Anxiety Level, The Ejection of Breast Milk. 


\section{PENDAHULUAN}

Air Susu Ibu (ASI) merupakan salah satu komponen terpenting yang produksi dan kelancarannya perlu diperhatikan oleh calon ibu. Begitu banyaknya manfaat yang akan didapatkan bagi ibu dan tentunya untuk bayi. Untuk menjamin pelaksanaan pemberian ASI, Pemerintah Indonesia membuat peraturan yang secara resmi yaitu Peraturan Pemerintah Nomor 33 Tahun 2012 yang didalamnya terdapat pernyataan bahwa bayi yang dilahirkan berhak mendapatkan ASI tanpa penambahan bahan makanan lainnya (tidak termasuk obat, mineral dan vitamin) hingga bayi memasuki usia enam bulan atau disebut sebagai ASI Eksklusif. Bahkan untuk mendukung keberhasilan dari pelaksanaan pemberian ASI Eksklusif pemerintah juga mengesahkan peraturan terkait dengan pelaksanaan ASI Eksklusif yaitu Peraturan Menteri Kesehatan (Permenkes) Republik Indonesia Nomor 15 Tahun 2013 tentang Tata Cara Penyediaan Fasilitas Khusus Menyusui dan/atau Memerah ASI.

Cakupan ASI eksklusif di Indonesia pada tahun 2010 adalah 33,6\%, meningkat menjadi $38,5 \%$ pada tahun 2011 dan $42 \%$ pada tahun 2012 serta mengalami penurunan pada tahun 2013 menjadi 30,2\%. Rendahnya cakupan ASI eksklusif secara Nasional tentu perlu mendapat perhatian lebih dari pemerintah. Penggalakan ASI memang bukan hal yang baru namun berbagai upaya untuk meningkatkannya terus dilakukan baik oleh pemerintah maupun swasta dan juga masyarakat peduli ASI, karena hasil cakupan ASI eksklusif belum mencapai target yang diinginkan secara Nasional yaitu sebanyak $80 \%$. Hal ini terjadi karena rendahnya pencapaian program ASI eksklusif pada setiap Provinsi dan wilayah Kabupaten dan Kota di Indonesia (SDKI, 2012; Kementerian Kesehatan Republik Indonesia, 2013; Riset Kesehatan Dasar, 2013).

Untuk merangsang pengeluaran hormon prolaktin dan oksitosin di Indonesia ada banyak jenis metode yang dapat dijadikan pilihan bagi ibu yang mengalami masalah selama menyusui, seperti pijat oksitosin, pijat prolaktin, pijat marmet, perawatan payudara dan lain sebagainya. Salah satu jenis pijat payudara yang tengah gencarnya dipromosikan oleh Jepang dan telah diterapkan sebagai sebuah program pendukung ASI Eksklusif di Bangladesh serta terbukti berhasil pelaksanaannya yaitu pijat oketani.

Gerakan pada pijat Oketani dan perawatan payudara bermanfaat melancarkan reflek pengeluaran ASI. Selain itu juga merupakan cara efektif meningkatkan volume ASI. Terakhir yang tak kalah penting, mencegah 
bendungan pada payudara (Saryono dan Pramitasari, 2008).

\section{TINJAUAN PUSTAKA}

ASI eksklusif didefinisikan sebagai bayi hanya menerima ASI dan tidak ada cair atau padat lainnya kecuali untuk tetes atau sirup yang mengandung vitamin, mineral atau obat-obatan (WHO, 2002).

\section{Faktor-faktor yang Mempengaruhi Pengeluaran/Kelancaran ASI}

Pengeluaran ASI dapat dipengaruhi oleh dua faktor yaitu produksi dan pengeluaran. Produksi ASI dipengaruhi oleh hormon prolaktin sedangkan pengeluaran dipengaruhi oleh hormon oksitosin. Hormon oksitosin akan keluar melalui rangsangan ke puting susu melalui isapan mulut bayi atau melalui pijatan pada area payudara ibu, dengan dilakukan pemijatan pada payudara ibu akan merasa tenang, rileks, meningkatkan ambang rasa nyeri dan mencintai bayinya, sehingga dengan begitu hormon oksitosin keluar dan ASI cepat keluar (Yanti, 2011).

Pijat merupakan salah satu solusi untuk mengatasi ketidaklancaran produksi ASI. Pijat adalah pemijatan pada area payudara dengan tekanan ringan hingga sedang dan merupakan usaha untuk merangsang hormon prolaktin dan oksitosin setelah melahirkan (Roesli, 2009). Pijatan ini berfungsi untuk meningkatkan hormon oksitosin yang dapat menenangkan ibu, sehingga ASI pun otomatis keluar.

\section{Pijat Oketani}

Pijat Oketani merupakan salah satu teknik pijat payudara yang berfokus pada daerah areola dan puting susu ibu. Teknik pijat yang diciptakan oleh Sotomi Oketani, salah seorang bidan dari Jepang, termasuk salah satu teknik pijat yang unik dan disebut sebagai Oketani Lactation Management. Dengan melakukan pijat ini, hubungan antara ibu dan bayi menjadi saling terkait satu sama lainnya secara fisik dan kondisi mental. Menurut Kabir (2009) ; Cho (2012) langkah - langkah pelaksanaan pijat oketani terdiri dari delapan. Serangkaian tahap pijat Oketani diselesaikan dalam waktu satu menit dan diulang selama 15-20 menit.

Ada beberapa manfaat yang akan didapatkan oleh ibu yaitu tidak menimbulkan rasa sakit atau rasa tidak nyaman, membantu meningkatkan produksi ASI, bagian payudara akan menjadi lebih elastis, seperti bagian areola, leher puting dan puncak putting, melancarkan saluran dan produksi ASI, pencegahan dan penanganan bagi ibu yang mengalami 
puting tenggelam, puting datar, atau puting terbenam.

Pijat Oketani juga akan memberikan rasa lega dan nyaman secara keseluruhan pada responden, meningkatkan kualitas ASI, mencegah puting lecet dan mastitis serta dapat memperbaiki/mengurangi masalah laktasi yang disebabkan oleh putting yang rata (flat nipple), putting yang masuk kedalam atau terbenam (Kabir, 2009).

\section{Kecemasan}

Kecemasan adalah emosi yang tidak menyenangkan, yang ditandai dengan kekhawatiran, keprihatinan, dan rasa takut yang kadang-kadang kita alami dalam tingkat yang berbeda (Atkinson, 1996 dalam Maimunah, 2011).

\section{Jenis Gangguan Kecemasan}

1. Gangguan Kecemasan

Gangguan Kecemasan Tergenalisasi, kekhawatiran merajalela.

2. Gangguan Obsesif-Kompulsif Inti dari gangguan ini adalah pikiranpikiran, gambaran-gambaran, dan implus-implus menggelisahkan yang tampak terus-menerus masuk ke dalam pikiran seseorang, kadang sepanjang siang dan malam.

\section{Fobia Sosial}

Adalah suatu ketakutan yang tidak rasional, yang menyebabkan penghindaran yang disadari terhadap objek, aktivitas, atau situasi yang ditakuti.

4. Post Traumatic Stres Disorder (PTSD) Adalah jenis anxiety disorder yang dapat terjadi setelah melukai atau mengancam kehidupan orang lain.

5. Gangguan Panik

Dicirikan dengan adanya serangan panik yang pertama sering kali spontan, tanpa tanda akan nada serangan panik, walaupun serangan panik kadangkadang terjadi setelah luapan kegembiraan, kelelahan fisik, aktivitas seksual, atau trauma emosional.

6. Social Unxity Disorder

Jika seseorang memiliki kekurangan dan takut akan penilaian negatif orang lain sehingga mereka takut orang lain akan menghina mereka didepan umum.

\section{Desain Penelitian}

Desain penelitian yang digunakan adalah quasi experiment dengan rancangan "One Groups Pretest-Posttest Design”yaitu 
desain penelitian yang terdapat pretest sebelum diberi perlakuan dan posttest setelah perlakuan. Dengan demikian dapat diketahui lebih akurat, karena dapat membandingkan sebelum dan sesudah diberi perlakuan.

\section{Populasi Penelitian}

Populasi penelitian ini adalah semua ibu menyusui eksklusif di Wilayah Kerja Puskesmas Pamulang Kota Tangerang Selatan.

\section{Sampel Penelitian}

Sampel pada penelitian ini adalah bagian dari populasi yang memenuhi kriteria inklusi dan ekslusi di Wilayah Kerja Puskesmas Pamulang Kota Tangerang Selatan.

\section{Besar Sampel}

Menurut Sugiyono (2011) jumlah sampel yang dapat digunakan dalam penelitian eksperimen berkisar antara 10 sampai 20 orang untuk tiap kelompok. Pada penelitian jumlah sampel yaitu 10 orang.

Kriteria inklusi dan eksklusi adalah sebagai berikut ini:

1. Kriteria Inklusi

a. Mempunyai bayi berumur 1-2 hari.

b. Masih memberikan ASI secara eksklusif. c. Bayi lahir tunggal

d. Memberikan persetujuan tertulis untuk berpartisipasi dalam penelitian.

\section{Kriteria Eksklusi}

a. Ibu mengalami stress dan penyakit infeksi.

b. Ibu yang menggunakan kontrasepsi hormonal.

c. Ibu yang sedang mengkonsumsi obat-obatan yang memiliki efek dopaminergik (kontrasepsi oral) antipsikotik (haloperidol, chlorpromazin, risperidone), antidepresi dan domperidon.

\section{HASIL PENELITIAN}

Penelitian ini telah dilaksanakan sejak tanggal 07 Maret sampai dengan 28 Juni 2019 di Wilayah Kerja Puskesmas Pamulang. Penelitian dilakukan terhadap 20 orang ibu nifas yang memenuhi kriteria inklusi yaitu ibu yang mempunyai bayi berumur 1-2 hari, memberikan ASI secara eksklusif, bayi lahir tunggal, tidak mengkonsumsi obat dopaminergik, tidak menggunakan kontrasepsi hormonal dan tidak dalam keadaan stress atau mengalami penyakit infeksi. Sampel pada penelitian ini sebanyak 10 orang dimana sebelum dilakukan intervensi dilakukan informed 
consent kepada responden. Selanjutnya responden dilakukan penilaian kelancaran ASI meggunakan kuesioner yang terdiri dari indikator ibu dan bayi serta tingkat kecemasan dengan menggunakan skala HARS. Pijat oketani selama 2 hari dengan menggunakan lembar observasi. Selanjutnya dilakukan penilaian kembali kelancaran ASI dan tingkat kecemasan pada setiap responden setelah intervensi.

\section{Perbedaan Kelancaran ASI dan Tingkat Kecemasan Sebelum dan Sesudah Dilakukan Pijat Oketani pada Ibu Nifas.}

Hasil penelitian kelancaran ASI dan tingkat kecemasan sebelum dan sesudah dilakukan pijat oketani pada ibu nifas dapat dilihat pada tabel berikut ini :

Tabel 1. Perbedaan Kelancaran ASI Sebelum dan Sesudah Dilakukan Pijat Oketani

\begin{tabular}{lcccc}
\hline \multicolumn{1}{c}{ Variabel } & $\mathrm{n}$ & Mean (SD) & $\mathrm{p}$ \\
\hline $\begin{array}{l}\text { Kelancaran ASI } \\
\text { Sebelum Dilakukan }\end{array}$ & & $(10,57)$ & \\
$\begin{array}{l}\text { Pijat Oketani } \\
\text { Kelancaran ASI }\end{array}$ & 10 & 12,50 & 0,016 \\
$\begin{array}{l}\text { Setelah Dilakukan } \\
\text { Pijat Oketani }\end{array}$ & & $(1,43)$ & \\
\hline
\end{tabular}

Tabel 1. menunjukkan bahwa mean kelancaran ASI sebelum dan sesudah pijat oketani pada ibu nifas adalah 10,3 dan 12,5. Hasil uji $\mathrm{t}$ dependen menunjukkan ada perbedaan kelancaran sebelum dan sesudah dilakukan pijat oketani pada ibu nifas $(\mathrm{p}=0,016)$.
Tabel 2. Perbedaan Tingkat Kecemasan Sebelum dan Sesudah Dilakukan Pijat Oketani pada Nifas

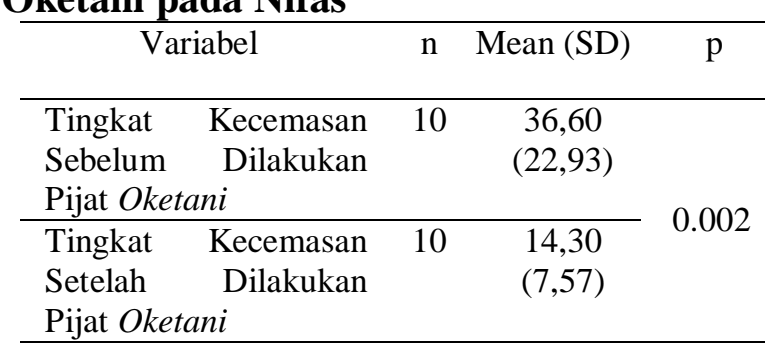

Tabel 2 menunjukkan bahwa mean tingkat kecemasan sebelum dan sesudah dilakukan pijat oketani pada ibu nifas adalah 35,11 dan 13,33. Hasil uji t dependen menunjukkan ada perbedaan tingkat kecemasan sebelum dan sesudah dilakukan pijat oketani pada ibu nifas $(p=0,006)$.

\section{PEMBAHASAN}

Perbedaan Kelancaran ASI dan Tingkat Kecemasan Sebelum dan Sesudah Dilakukan Pijat Oketani pada Ibu Nifas

Berdasarkan hasil penelitian ini terlihat bahwa terdapat perbedaan kelancaran ASI dan tingkat kecemasan pada masing-masing responden. Pada kelompok setelah dilakukan pijat oketani memiliki nilai mean yang lebih tinggi dibandingkan dengan nilai mean sebelum dilakukan pijat oketani. Hasil analisa bivariat menggunakan $\mathrm{t}$ dependen menyatakan bahwa ada perbedaan kelancaran sebelum dan sesudah dilakukan pijat oketani pada ibu nifas di Wilayah Kerja Puskesmas Pamulang 
Untuk merangsang hormon prolaktin dan oksitosin selain dengan memerah ASI juga dapat dilakukan dengan melakukan pemijatan pada payudara. Gerakan pijat oketani dan perawatan payudara akan membuat aerola, duktus laktiferus dan puting susu menjadi lebih elastis dan juga merangsang hipotalamus, selanjutnya akan merangsang adenohipofise (hipofisis anterior) sehingga mengeluarkan prolaktin. Hormon ini merangsang sel-sel alveoli yang berfungsi untuk membuat air susu. Bersamaan dengan pembentukan prolaktin oleh hipofisis anterior, rangsangan dilanjutkan ke neurohipofisis (hipofisis posterior) sehingga mengeluarkan oksitosin. Selanjutnya oksitosin diangkut oleh darah ke payudara untuk menimbulkan kontraksi sel-sel mioepitel. Kontraksi dari sel-sel mioepitel akan memeras air susu yang telah dibuat oleh alveoli dan masuk ke sistem duktulus, selanjutnya mengalir melalui duktus laktiferus sehingga terjadi pengeluaran ASI (Kabir \& Tasnim, 2009; Anggraini, 2010; Guyton and Hall, 2014). Akan tetapi, apabila seseorang mengalami ketegangan dan kecemasan yang bekerja adalah sistem saraf simpatetis, sedangkan saat rileks adalah sistem saraf para simpatetis. Jika sistem saraf simpatetis meningkatkan rangsangan atau memacu organ tubuh, memacu meningkatnya denyut jantung dan pernafasan, serta menimbulkan penyempitan pembuluh darah tepi (peripheral) dan pembesaran pembuluh darah pusat, maka sebaliknya sistem saraf parasimpatetis menstimulasi turunnya semua fungsi yang dinaikkan oleh sistem saraf simpatetis dan menaikkan semua fungsi yang diturunkan oleh sistem saraf simpatetis. Maka relaksasi dapat menekan rasa tegang dan cemas yang dapat menimbulkan rangsangan ke hipotalamus sehingga oksitosin menurun dan menurunkan kelancaran ASI (Andriana, 2006).

Yuliati, (2017) bahwa kombinasi pijat rolling dan pijat Oketani terbukti mampu meningkatkan kadar hormon prolaktin dan juga meningkatkan produksi ASI sehingga menyebabkan ASI lancar. Selain itu, manfaat positif juga ditemukan pada komposisi ASI dari ibu menyusui di usia <3 bulan dan >3 bulan yang mendapatkan pijat Oketani. Kadar protein pada ASI menjadi lebih baik gizinya pada ibu tersebut (Foda, Oku, 2008).

Hasil penelitian Kusumastuti, dkk (2018) juga menyatakan bahwa seluruh ibu post partum yang dilakukan pijat oketani sebanyak 22 orang (100\%) tidak mengalami bendungan ASI. Sedangkan pada ibu post 
partum yang tidak dilakukan pijat oketani didapatkan 17 orang $(77,3 \%)$ mengalami bendungan ASI. Hasil analisis paired t-test diperoleh $\mathrm{p}$ value $=0,021$, hal ini menunjukkan bahwa pijat oketani pada ibu post partum efektif dalam pencegahan terhadap bendungan ASI. Kesimpulan dari penelitian ini menyatakan bahwa kejadian bendungan ASI efektif dapat dicegah dengan pijat oketani.

Ditemukan ada perbedaan kelancaran ASI dan tingkat kecemasan sebelum dan sesudah dilakukan pijat oketani. Pijat oketani yang diberikan merasakan keadaan yang tenang, santai, rileks, dan nyaman dalam menyusui bayinya sehingga menyebabkan peningkatan kadar oksitosin dan ASI lancar.

\section{KESIMPULAN}

Kesimpulan penelitian ini adalah ada perbedaan kelancaran ASI dan tingkat kecemasan sebelum dan sesudah dilakukan pijat oketani pada ibu nifas.

\section{DAFTAR PUSTAKA}

Anggraini, Yetti. 2010. Asuhan Kebidanan Masa Nifas. Yogyakarta: Pustaka Rihana.

Buhari, S. 2018. Perbandingan Pijat Oketani Dan Oksitosin Terhadap Produksi Air Susu Ibu Pada Ibu Post Partum Hari Pertama Sampai Hari Ketiga di Rumah Sakit TK II Pelamonia
Makassar. Jurnal Kesehatan Delima Polamonia: Makassar.

Diaz S, Seron-ferre M, Croxatto, HB, Veldhuis J. 1995. Neuroendocrine mechanisms of lactational infertility in women. Biol Res. 28 (2):15563.Review.Pubmed PMID.(March 2016).

Febrina, I. 2011. Hubungan Tingkat Kecemasan Pada Primipara Dengan Kelancaran Pengeluaran ASI Pada 2-4 Hari Postpartum Di Wilayah Kerja Puskesmas Kecamatan Lubuk Kilangan. Diakses pada 26 November 2018

Gimpl G, Fahrenholz F. 2010. The Oxytocin Receptor System: Structure, Function and Regulation, 81(2), 629-683.

Guyton AC, Hall JE. 2006. Textbook of Medical Physiology, $11^{\text {th }}$ Ed. Philadelphia, PA, USA: Elsevier Saunders

Jameson JL, Groot LJD, Kretser D, Grossman A, Marshall JC, Melmed S, et al., 2010. Endocrinology Adult and Pediatric. $6^{\text {th }}$ ed. saunders Elsevier, 165-178.

Qiftiyah, M. (2017). Studi Tingkat Kecemasan Ibu Post Partum Terhadap Kelancara ASI Pada Ibu Nifas Hari Ke5 (Di BPM Asri Dan Polindres Permata Bunda Tuban).

Riset Kesehatan Dasar (Riskesdas). 2013. Badan Penelitian dan Pengembangan Kesehatan Kementerian Kesehatan RI Tahun 2013.

Riksani, R. 2012. Keajaiban ASI (Air Susu $I b u)$. Jakarta Timur: Dunia Sehat 
Roesli, U. 2009. ASI Eksklusif. Trubus Agriwidya.: Jakarta.

Tyfani. 2017. Hubungan Antara Pelaksanaan Perawatan Payudara dengan Kelancaran ASI Ibu Postpartum di Kelurahan Tlogomas Kecamatan Lowokwaru Kota Malang. Jurnal Kesehatan Fakultas Ilmu Kesehatan Universitas Tribhuwana Tunggadewi Malang

Sri, W., Rahmad, G. 2012. Pengaruh Perawatan Payudara (Breast Care) Terhadap Volume ASI pada Ibu Postpartum (Nifas) di RSUD Deli Serdang Sumut Tahun 2012. Jurnal Kesehatan STIKes Medistra Lubuk Pakam.

Stables D, Rankin J. 2010. Physiology in Childbearing with Anatomy And
Related Biosciences. $3^{\text {th }}$ Ed. Bailliere Tindal Elsevier, 723-738.

Survei Demogrofi Kesehatan Indonesia (SDKI). 2012. Survey Demografi Kesehatan Indonesia. Akses 11 Januari 2015. BKKBN., BPS., Kemenkes, R.I, Measure DHS\&ICF, I. http://www.depkes.go.id/resources/do wnload.pdf

World Health Organization. 2002. Infant and child nutrition: global strategy on infant And young child feeding. Akses 11 Oktober 2015. Available at: http://apps.who.int/gb/archive/pdf_file s/WHA55/ea5515.pdf.

World Health Organization .2002. Infant and child nutrition: global strategy on infant And young child feeding. Akses 11 Oktober 2015. Available at: http://apps.who.int/gb/archive/pdf_file s/WHA55/ea5515.pdf 